\title{
4 The world as an exiling political structure
}

\section{Yassin al-Haj Saleh's conceptualisation of exile}

\author{
ElSayed Mahmoud ElSehamy
}

\section{Introduction: an overview on al-Haj Saleh}

This chapter describes Yassin al-Haj Saleh's conceptualisation of exile. Al-Haj Saleh is a widely known Syrian writer and scholar who participated in the 2011 Syrian revolution from the early beginnings and started writing about the emerging events that accompanied the popular uprising. I provide a brief biographical overview on his life before showing how he operationalises exile analytically as practices of exclusion and marginalisation, what he calls 'exilement'. Throughout the chapter, I construct a narrative from a selection of his work, which was published in Arabic mostly after the Syrian revolution in 2011. Putting fragments together, I illustrate my understanding of his views of exile as an act of negation of history through political eternity, freedom through political imprisonment, and home through exile and displacement by the exiling authority. Adding to this, I elaborate on al-Haj Saleh's understanding of exile as exemplified by some predominant practices of exclusion in Syria, such as oblivion, rape and enforced disappearances which also conspire to negate Syrians' political rights. Building on that, I illustrate how he contends the negation of these negations through the processes of 'enjailment' 1 and 'exilification' as attempts at 'exiling exile'. I show how he differentiates between being a refugee and being an exile, and how exile is a liminal, (in)dependent experience that is everywhere and nowhere at once. I conclude by showing how he argues for the end of exile, by illustrating how the world became an exile from one side and how exile is a contemporary global phenomenon from the other.

In his early youth, al-Haj Saleh was a member of the Syrian Communist Party. Al-Haj Saleh was among many who were arrested in the 1980s because of their political activism against Hafez al-Assad's regime. He spent 16 years in Aleppo Central Prison, Adra Prison and the notorious Tadmor prison, between 1980 and 1996. As "a child of the prison," his experience of imprisonment represents a significant formation of his political thought. ${ }^{3} \mathrm{He}$ learned English in prison. Upon his release, he was never allowed a passport. He started to work on political journalism and translation, playing an active role in redefining the role of the "public intellectual' through his works. ${ }^{4}$ Al-Haj Saleh's personal life is part of the Syrian tragedy and his writing is a by-product of a constant mediation between the analytical, the observatory

DOI: $10.4324 / 9781003092421-6$ 
and the participatory. ${ }^{5}$ When the Syrian revolution broke out in March 2011, he was in Damascus. To avoid police arrest and self-censorship while writing about the revolution, he lived in hiding for two years. ${ }^{6}$ In 2013 , he was smuggled from Damascus into Ghouta through a network of tunnels, passing by his native city of al-Raqquah and ending up in Turkey. The film Our Terrible Country (Baladna al-Rahib) shows part of his life in hiding and his journey throughout the 'liberated' zones of Damascus. Upon arrival in his native al-Raqquah, as the epic film shows, al-Haj Saleh finds that The Islamic State of Iraq and the Levant (ISIS) had taken the city as its capital, which led him to continue hiding until he reached Turkey. During his journey, he kept contact with his wife, Samira al-Khalil, a former political prisoner of the regime of Hafez al-Assad and a political activist. On the way to Turkey, he learned that his brother, Firas, had been abducted by ISIS. In December 2013, upon his arrival in Turkey, Samira al-Khalil was abducted along with her fellow prominent activists Razan Zeitouneh, Wael Hamadeh, and Nazem Hamadeh, in the besieged city of Douma, by an Islamist militant group. Their whereabouts are still unknown. ${ }^{7}$ Al-Haj Saleh was a refugee in Turkey from 2013 to 2017 and is now a political exile in Berlin.

Exile is not a main theme in al-Haj Saleh's works. His writings on exile are fragmented and scattered throughout many of his essays, which were published mostly in Arabic. Additionally, his work on exile is not widely known beyond the Arab world. Being the first account that taps into this subject thoroughly in the light of post-2010 Arab revolutions, drawing scholarly attention to his work is also important because it is an emerging account that aims to articulate the phenomenon of exile beyond its personified, literary and/or figurative aesthetics. ${ }^{8}$ Al-Haj Saleh's work develops analytical tools for studying exile as "a political institution of dictatorship". ${ }^{9}$ In the way he conceptualises exile, as I show, lies a story about Syrian social formation. His emergent account of exile is evidence of how practices and knowledge are formed through experiences of imprisonment, forced disappearance, displacement, refuge, and exile. His account goes beyond methodological nationalism and theoretical Eurocentrism by employing a non-state-centred perspective of conceptualising exile, which challenges the primacy of static forms of political membership. He reflects on his exile as a condition of political and cultural significance, showing that exile is a site of personal growth and a source of political awareness that enables understating the complexities of the social.

Al-Haj Saleh is often referenced for his political analysis and intellectual trajectory. He has been expressing the hopes and the challenges of the revolution. He is widely considered the "conscience of the Syrian revolution" and the "sage of the Syrian revolution" (hakim al-thawra), due to his explicit analysis and critique of power relations under the Assad regime, sectarianism, and political Islam. Massouh ${ }^{10}$ provides an overview of al-Haj Saleh's life and scholarly productions about Syria, situating his intellectual contributions in wider themes in contemporary Arab thought. He argues that al-Haj Saleh upholds a humanistic, ideal way of critique as a form of agency and social responsibility. Al-Haj Saleh seeks to denaturalise assumptions about 


\section{2}

ElSayed Mahmoud ElSehamy

authoritarianism and sectarianism in contemporary Syria throughout his cultural, discursive productions, "in an effort to expand the parameters of both what is imaginable and what is doable". ${ }^{11}$ While Massouh tackled alHaj Saleh's scholarly productions and public activities in exile, he did not demonstrate al-Haj Saleh's understanding of exile. Haugbolle (2015) analyses the film Our Terrible Country to discuss debates about revolution, exile and representations in Syria and the Middle East. He interrogates the role of intellectuals as 'revolutionary icons', and their work in the path of revolutions and counter-revolutions, depicting al-Haj Saleh's role in the Syrian Revolution. Al-Haj Saleh represents an intellectual leadership that is inspired by his life history and his scholarly productions, inspiring "collective action and reflection that is meant to transform the social imaginary and prepare the social conditions conducive for revolution". ${ }^{12}$ While Haugbolle argues that exile produces self-critique, he tapped into how exile and defeat influenced al-Haj Saleh to produce radical critiques of the Syrian state, Islamism and modernity. Yet, how al-Haj Saleh understands exile is still missing in the academic literature. (Figure 4.1).

\section{Al-Haj Saleh's use of exile: exilement as practices of exclusion}

For al-Haj Saleh, we cannot only look where the exiled is, but from where and how they come to be as such. In Arabic, the word 'exile' (al-manfa) is the gerund of the verb 'to negate something'. Based on this linguistic conceptualisation of the word, al-Haj Saleh tends to use 'exile' for any action negating another with relations of dispossession, disenfranchisement and marginalisation. Thus, in his view, 'to negate' is synonymous with 'to exile'. He locates 'exile' within an

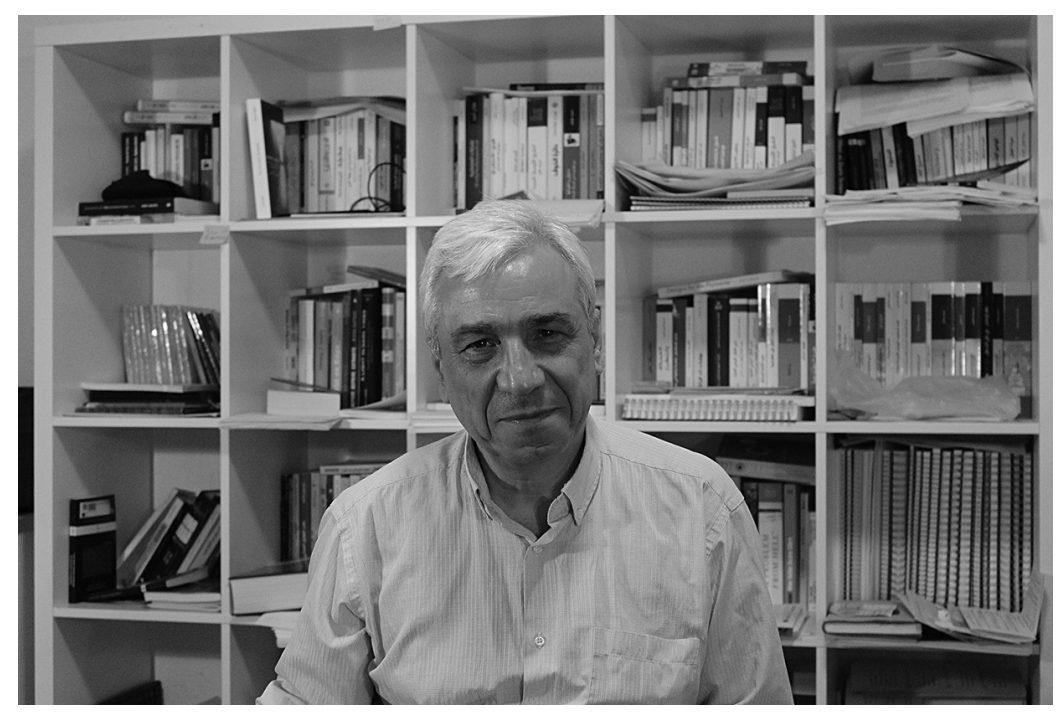

Figure 4.1 Yassin al-Haj Saleh. Image by Yassin Swehat, February 2021. 
analytical (exiling) complex, in which an exiling authority is embedded in an exiling political structure, which exiles individuals through the processes and practices of exilement. ${ }^{13}$ Exilement is the practices and forces that lead to the production of individual exiles. These processes of exilement, violent in their nature, give analytical views on the social structure of the Syrian revolution. ${ }^{14}$ Hence, for al-Haj Saleh, exile adopts multiple manifestations. To exile an individual or a population would mean to deprive them of their rights. In that perspective, al-Haj Saleh does not reduce 'exile' to losing the homeland and being a refugee. Erasure of a person's points of reference is a form of exile, being black in a white-dominated society is being an exile, being forced to do compulsory conscription is exile of an individual's freedom, and writing about exile is one way of exiling that exile.

Exiling exile refer to the attempts to negate what exilement aims to negate. It is a negation of negation. If death, in necropolitics, is a space where freedom and negation operate, ${ }^{15}$ exile is a space in which the negation of freedom and the negation of that negation interact. As losing one's homeland, for example, is an effect of exile, the negation of exile requires a recreation of what might be a 'home' otherwise. Al-Haj Saleh expands the understanding of exile to analyse it in structural terms. As he does not separate the phenomenon of exile from the political situation from which it emerges, he puts it in association with other phenomena that are common in that context. He juxtaposes the experience of exile with experiences of political imprisonment, forced disappearance, rape, and oblivion (al-mansa). These phenomena are inseparable. They are generative, procreative and bleed into each other. In the following paragraphs, I illustrate the way in which al-Haj Saleh characterises these phenomena as forms of exilement.

\section{Political eternity as an exile: exiling history through 'political' eternity}

Political eternity is the planned duration of the Assad regime's rule in Syria and the intention of staying in power forever, through sectarianism, dynasty and inheritance. Al-Haj Saleh builds his understanding of eternity on Snyder's 'politics of eternity' 16 to indicate that eternity means ensuring the eternal rule of the Assad dynasty over Syria. ${ }^{17}$ Starting from 1980, slogans such as 'Assad or we burn the country,' 'Assad or nobody,' 'Assad or to hell with the country' and 'Hafez Assad, forever' became dominant in Syria. ${ }^{18}$ Such slogans were the daily practices of the regime, aspiring to instil its dynasty in rule forever through sectarianism and racism. ${ }^{19}$ Analysing state formation under the Assad regime from the 1980s, al-Haj Saleh argues that the Assadist state is not only a dictatorship, but a dictatorship with genocidal tendencies. $^{20}$ The violent suppression of peaceful mass protests that broke out across Syria in 2011 and the militarisation of the revolution was a product of a genocidal state which itself is an accumulation of a long history of domination, humiliation, and sectarianism.

For al-Haj Saleh, the etymological relations in Arabic between eternity ( $a b a d)$ and genocide (ibada) is not a coincidence. The Assadist regime's plans 
for eternity were "intimately bound up with massacres and extermination... and broadening of killing for the purpose of securing power over time, and of preventing change". ${ }^{21}$ Eternity, then, is a form of preventing the future from coming by fixating the present and exterminating whoever seeks change, whether individuals, movements or institutions. It is a war against the future. From launching wars and wholesale massacres, the regime takes its main policy, namely "to exterminate opponents politically and morally by denying that they have a public cause; to exterminate them physically by declaring that their annihilation is required". ${ }^{22}$ The violence of the Assad regime is structural, a first choice, not the last. In that context, the death of the ruler cannot exile this eternity, as the regime seeks to reproduce itself by whatever means. When the death of the father is an inauguration of the beginning of dynasty rule, the son, as the only and absolute heir, takes power to establish his own dynasty. ${ }^{23}$

In that mode of rule, politics are exiled, prevented and abstained from. The dynamism of any political life in that society is fixated yet exiled. Thus, a form of political routine becomes dominant and politics lose their meaning. The Assadist regime's practices of entrenching eternity caused a state of politicide to the majority of Syrians, that is a complete destruction of any and all independent political organisations of any sort. ${ }^{24}$ "There is no room for real politics under eternity, absolutism, [and] personified power," writes al-Haj Saleh in his latest book in which he analyses the workings of Assadist rule. ${ }^{25} \mathrm{He}$ refers to this state as a process of "enslavement" in which Syrians lacked their basic political rights. ${ }^{26}$ When he was asked about the reason for joining the revolution, without any hesitation - although he knew that it might backlash on him - he answered: "I want to see Syria while it changes after I spent half a century of my life without seeing it change". ${ }^{27}$

Political eternity, in that sense, is exile from history and socio-political change. ${ }^{28}$ For al-Haj Saleh, Syrians were politically exiled because of the deprivation of their political rights and living a constant bare existence. ${ }^{29}$ However, the 2011 Syrian revolution represents a rupture that breaks this exilement of history and is an attempt to enter history after more than four decades of exile. A regime that causes exile became exiled itself as the revolution aimed to fragment its absolute sovereignty. The Assadist regime navigates its own opportunity to remain as a political actor on the Syrian scene, but not the only one, especially after foreign interventions in Syria and the emergence of Islamist militant groups. ${ }^{30}$ By this partial loss of sovereignty and entry to a socio-political history that necessitates political change and social transformation, "the Assadist state became an exile from history itself" ${ }^{31}$ The Syrian revolution is a historical moment as it broke Assadist eternal rule and forced it to move from eternity into the temporary.

This is what al-Haj Saleh means by living in exile while he was a 'citizen' in Syria: "I still find it difficult to reconcile myself to the word exile. I used to observe it with the eyes of a prisoner, then with the eyes of a 'citizen' living in Syria." ${ }^{32} \mathrm{He}$ was politically exiled inside the country, as a prisoner and as a 'citizen'. ${ }^{33}$ In al-Haj Saleh's words, it can be said that the Assadist regime was the exiling authority, located in an exiling political structure of the politics of 
eternity, which exiles Syrians from politics and history. In the following section, I discuss how al-Haj Saleh illustrates the negation of freedom through prison by juxtaposing the experience of prison with exile.

\section{Political jail as exile: exiling freedom through jail and exile}

Al-Haj Saleh juxtaposes political imprisonment with exile, the effect of displacement. If we are forbidden to come out of the house in which we live, for al-Haj Saleh, the house becomes a prison. And if we are 'imprisoned' outside the house, or the country, it is prison in the form of exile; "prison is an exile to the inside from which we are not allowed to go out, and exile is a prison in the outside from which we cannot return". ${ }^{34}$ Thus, imprisonment outside the country is dispossession of the freedom to return, and therefore exile. Imprisonment inside the country and the prohibition of coming out is also exile. Exilement here is the act of negating the freedom of going out of the prison and negating the freedom of returning to the country. In that sense, exile is a continuation of prison.

Exile was a legal punishment in colonial settings, by which natives who rebelled against colonial social and political norms in the colonies were forcibly relocated to deserted and remote areas. Exile, which was often referred to as "deportation", was a way of isolating "political undesirables" outside their county. ${ }^{35}$ Prison is a place of exiling rights and isolating "undesirables" inside the country. With the suspension of exile as a legal punishment, prison became the punishment which substitutes and equates exile. ${ }^{36}$ Both experiences are common in terms of their negation of freedom and rights, and the confinement of subjects inside and outside their countries.

The exiling act, in prison and exile, is violence perpetrated by an exiling authority - here the Assadist Syrian state. ${ }^{37}$ The brutality of political prison as an unlawful space of incarceration lies at the heart of contemporary Syrian society and its recent conflict, rendering Syria as a "space of exception". 38 Much of al-Haj Saleh's writing deals with the question of prison, as emblematic of al-Assad's rule. ${ }^{39}$ However, exilement in the Syrian context is not limited to politics of eternity, imprisonment and displacement; it can also be associated with other common phenomena in the Syrian context, such as forced disappearance, rape and oblivion since these are deployed as types of political punishment and modalities of governance.

\section{Marginalisation as exile: oblivion, rape and enforced disappearance in Syria}

Oblivion (al-mansa) is the state of not being publicly remembered or honoured and being forgotten and invisible. ${ }^{40}$ It is a state of being banished from public speech and the national memory. Oblivion is a state of non-representation, in which only the ruler is remembered and commemorated, and all Syrians are oblivionated and rendered invisible. The oblivionated (i.e. the made-absent by force) are groups of people who are dehumanised and 
humiliated, and ultimately die without being mentioned or remembered publicly. They are products of power relations, similar to exiles and the imprisoned. The oblivionated are "exiles inside their countries, outside public remembrance and the public sphere. They are unrecognized and unseen. No one thinks about them. Their narratives and stories are untold. Their voices are silenced, and their images are removed" as a result of relations of dehumanisation and humiliation..$^{41}$

Al-Haj Saleh takes the victims of the Hama massacre in 1982 as an example of an oblivionated population. In February of that year, the city of Hama was besieged by the Syrian Arab Army for 27 days under the orders of Hafez al-Assad to suppress an uprising by the Syrian Muslim Brotherhood against the regime's government. The city was heavily bombarded and large parts of the city were destroyed. The numbers of victims are still unknown. A Syrian journalist estimates that by invading the city, the army killed between 30,000 and 40,000 of the city's citizens, in addition to 15,000 missing and 100,000 expelled. ${ }^{42}$ Ismail (2018) studies the silence about the Hama violence, the unsaid, that was present in Syrians' lives, arguing that Hama functions as a pedagogy of rule and instructive of the powers of the ruler. She contends that Hama was "a gap in narratives of the Syrian experience of life under the Hafez al-Assad dictatorship" ${ }^{43}$ For al-Haj Saleh, the victims (and the witnesses) of Hama were killed twice: once in the massacre and the other by oblivionation. The 2011 revolution was against this state of invisibility, and an attempt to own politics and the public sphere. According to al-Haj Saleh, this state of oblivion is one of the causes of the revolution, which is often undermined by Western discourses about Syria (see below).

Al-Haj Saleh explicitly analyses prison torture dynamics, inspired from his time behind bars. It is important to note that the political prisoner in Syria is not an exception, but the general rule. The prison camp is an apparatus of governmental violence that structures subject-state relations in Syria. ${ }^{44}$ Al-Haj Saleh distinguishes between three types of torture: "interrogatory or investigatory torture, humiliatory-retaliatory torture, and genocidal or exterminatory torture" ${ }^{45}$ Humiliatory torture is a dominant form in Syria that seeks to exterminate its subjects and permanently enslave them in case of survival. He argues that neither society nor the state aids the prisoner in their rehabilitation after release. Actually, the state keeps the (former) prisoner in a permanent state of terror and horror by keeping them always in check. ${ }^{46}$ Genocidal torture is aimed at systematically killing the masses by multiple forms, not merely by torture, but by creating death-worlds in which the subjects are disposable and exposed to extreme conditions of hunger, disease, siege and terror. Massacres, barrel bombs, and sarin gas feature among the tools deployed by the torture machine. ${ }^{47}$ This form of torture, al-Haj Saleh argues, is one of the aspects which the Assadist regime adopted after 2011 to crush peaceful protests.

With tens of thousands of women, men and children being raped in Syria during wartime by the regime's forces and other militant groups ${ }^{48}$ rape is weaponised as pure humiliation and a genocidal tool. Rape, Al-Haj Saleh 
argues, exiles the raped self by objectifying and possessing it. It shatters and disentangles the individuality of the rape victim by literally invading and occupying their body aggressively as aspects of claiming sovereignty and control. ${ }^{49}$ For al-Haj Saleh, rape aims at not merely destroying women's bodies but also the families to whom they belong. Disrupting women's reproductive system is about disallowing their families to biologically reproduce themselves. Al-Haj Saleh asserts that rape, then, is not only about exiling women's individualities from themselves and their society, but their families and the groups to whom they belong. ${ }^{50}$

Forced disappearance is another form of exilement, added to rape and oblivion. Tens of thousands of people remain disappeared since 2011, according to Amnesty International. ${ }^{51}$ The disappeared include humanitarian workers, lawyers, journalists, peaceful activists, government critics and opponents, along with individuals detained in place of relatives wanted by the authorities. Al-Haj Saleh considers disappearance as a way of exiling the disappeared from their communities, by denying their existence. They are in a space between life and death. Disappearance also, like rape, exiles the communities to whom the missing belong by denying them the right to know where and how they are. Their families live in a state of uncertainty and are always in check. Those missing become part of the unknown. Disclosing their destinies is a way of negating them. The disappeared are in exile, in Syria.

I believe that the experience of living in hiding and being on the run can be associated with the experiences mentioned above. Al-Haj Saleh himself lived in hiding for more than two years to avoid police arrest and/or self-censorship while writing. The film Our Terrible Country shows part of his life in hiding. On a different note, in al-Haj Saleh's view, political prison and exile are interrelated and interlinked and they can be utilised as spaces of freedom and emancipation. In the following sections, I demonstrate what al-Haj Saleh means by attempts to exile exile through the processes of enjailment and exilification.

\section{Enjailment and exilification: emplacing ourselves and homing places}

Before I discuss enjailment and exilification as potentials for freedom in spaces of confinement, I briefly demonstrate al-Haj Saleh's understanding of 'freedom' which is connected to his understanding of exile, prison, self and home. For al-Haj Saleh, freedom signifies change, transgression and adventure. A free person is dynamic, changeable and flexible. Freedom is movement from one condition to another. In this understanding, coming out of the self by constantly changing it is a liberating act and a (pre)condition for freedom. Coming farther out of the self by breaking the daily routine can be not only a liberating but also a transformative experience. ${ }^{52}$ For al-Haj Saleh, the inner self of an individual can be a suffocating prison. Habits, beliefs, ideologies and traditions can be (inner) acts of confinement and detention by other means. Then, changing the self by welcoming different ideas and transgressing our beliefs is a liberating action of enlivenment and expansion, 
through hospitality towards others and their cultures. ${ }^{53}$ As the self can be a prison, it can also be a home. When we welcome others, we change them and our places, not only ourselves: "Open homeliness means to go towards others and others come to us... and we form shared homes, and the other does not remain other." 54

When a prisoner turns their prison into a home, an opportunity for personal development, al-Haj Saleh calls it 'enjailment'. ${ }^{55}$ Through the process of enjailment, a prisoner naturalises time in prison with productive activities by homing the prison and transforming it into a framework of (self-)change. ${ }^{56}$ For al-Haj Saleh, "enjailment cancels prison, deactivates it, and converts it into a space for liberation" from inner prisons. ${ }^{57}$ Prison provides the time to existentially re-think our beliefs and re-define ourselves. There is no other way for the prisoner to emancipate themselves than turning a physical prison into an avenue for liberation..$^{58}$ Enjailment, then, is "a conflict we undertake in prison against prison" by searching for freedom inside the prison..$^{59} \mathrm{In}$ his years in Syrian prisons, al-Haj Saleh himself changed and he reconsidered his views of politics. His understanding of communism became different from what it was before, and he started to oppose any dogmatic belief. ${ }^{60}$ His ways of enjailment were reading, writing, watching TV, playing cards and sleeping. The act of writing offered him a way out from prison's harsh experiences. Al-Haj Saleh talks about temporality in prison and how time stands still. Enjailment is, also, a form of owning time by turning it into one's own selfdevelopment. Like enjailment, turning exile into home is 'exilification'.

Exilification is the attempt to turn the exile home. The exiled makes from their exile an opportunity and a new beginning to resume a life that has been put on hold ${ }^{61}$ Exilification is a way of accepting the conditions and the challenges of exile, and starting new commitments for a different world; neither by isolating oneself from the new social environment in expectation of going back home nor full dissolution in the new society, in an attempt at complete erasure of the past. ${ }^{62}$ It is a state of in-betweenness, of balancing being "from there and from here" at once. ${ }^{63}$ Following this understanding, maintaining the old constitution of the self and considering it an act of resistance is counterproductive. ${ }^{64}$ "Holding on to an old self out of national loyalty is the true treason. We need in exile, as in prison, to change ourselves, to become free" al-Haj Saleh affirms. ${ }^{65}$ The relative separation of the 'old' society, traditions and habits is the only thing that liberates the exiled, according to al-Haj Saleh. ${ }^{66}$ By rendering exile into a new beginning, a different struggle added to the 'old' one in the home country, the exiled does not spend the rest of their years awaiting return. However, they try to live in exile not around it. ${ }^{67}$

Exilification can manifest itself in multiple practices. Establishing friendships eliminates the foreignness of a place and reduces its identity as exile. ${ }^{68}$ Friendships help exiles to emplace themselves in new destinations and build their identities and lives in new conditions. ${ }^{69}$ Another way of exilification for al-Haj Saleh personally is through work; writing functions as a bridge to Syria and public engagement connects him to other Syrians in exile. For him, public engagement is an attempt to build a different Syria from where he is. He takes 
from writing an identity and "a method to explain the world and to navigate in it, indeed for being in the world: a chosen nation. Because of writing... I have not suffered the problems of most exiles"..$^{70}$ In addition, learning the language of the host country familiarises the exiled with the place and makes its intensity as such less counterproductive and fosters inhabitance therein. Having a house to live in helps the exiled also to reconcile their past and accept the new conditions. Moreover, exile provides the opportunity to rethink our beliefs from inside out and ponder the path the exiled has reached so far. Also, exile can be an emancipatory experience for rethinking politics, history and progress. ${ }^{71}$

For al-Haj Saleh, exile can only be an emancipatory experience if the exiled takes it to change themselves and develop their ideas about the nature of the world. ${ }^{72}$ As movement and change are constitutive of freedom, exile is an act of and a path for freedom, however hard. It is a path for freedom as it was an effect of seeking it. Exilification is a non-national attempt at exiling exile. Nationalism and/or nation-centric practices do not exile exile. Exiling exile is efficient by exiling the nation itself, as the nation is the cause of exile. ${ }^{73}$ Nonnational exiling of exile can be manifested in multiple ways, including not taking the nation or ethnic identities as the main reference point, producing non-national representations of what home might be, or developing holistic research methodologies while investigating place-making practices from a multiscalar perspective. ${ }^{74}$ It is noteworthy to add that exilification is not an oriented, fixed process with guidelines, but a way of becoming and flourishing. In al-Haj Saleh's understanding, exile is being flexible.

It should be underlined that the processes of enjailment and exilification can only be done depending on their social structures. For example, a prisoner cannot enjail if they are exiled into notorious prisons like Palmyra or Sednaya military prisons. The refugee cannot exilify if they live in hard conditions, in a camp or a tent, in short the case of thousands of Syrians in Idlib, Lebanon, Jordan and Turkey. ${ }^{75}$ In these cases, the conditions of exile are a continuation of the experience of uprooting and dispersal.

\section{Living around exile: the liminality and (in)dependency of exile}

For al-Haj Saleh, exiles need to resist the exile's regime of temporality and spatiality. The majority of Syrian refugees do not live in camps or tents. Those living in camps, out of an overall total of 6.7 million displaced Syrians, ${ }^{76}$ are living "a suspended life". They live in the temporary, meaning that they not only live "in a strange place but [also] live in the time that separates what was before from what is after". ${ }^{77}$ They keep struggling with the space and time in which they live before and after their displacement. For other Syrians who live a more or less 'normal' life, "the past suddenly seems to be the time of freedom and the present is confusion and anxiety, while the future is a hoped-for return or a sustained confusion and struggle". ${ }^{78}$ Recognising the stuckedness of/in exile's temporality is part of exilification. ${ }^{79}$ Exile is a liminal status of being torn between the conditions of exile and a destroyed country. ${ }^{80}$ As exiled Syrians are outside their country, their personal experiences become more and 
more centred around living abroad. However, the conditions of exile make them look back for their loved ones who have been kidnapped, detained or disappeared inside - that is, they are living around 'exile' not in exile. ${ }^{81}$ This makes the autonomy of exile impossible and renders exiles not just exiles but part of simultaneous social formations. ${ }^{82}$

For al-Haj Saleh, exile is an experience of contradictions. It is dependent, as it is a new beginning. However, it is also independent because of the histories of the exiled. This combination of (in)dependency is "the essence of the experience and its source of uncertainty" ${ }^{83}$ The processes of exilification and enjailment are, then, about homing the (foreign) time not only the (foreign) places. ${ }^{84}$ The word 'exile' is not adequate to describe the case of most Syrian refugees. Exile cannot be subsumed into and limited to a certain space or time. The embodiment of the experience of exile reshapes and remakes the space-time nexus: when histories of anxiety and oppression are accumulated and materialised on an individual's body wherever they go. This is not to say that 'exile' does not have its own autonomy, characterising it with different regimes of spatiality and temporality separated from their surroundings. ${ }^{85} \mathrm{To}$ the contrary, al-Haj Saleh's account neither depoliticises nor de-historicises the experience of exile. He accounts for its particularity and personal mediation; however, he does not essentialise it as such. Then, exile is an experience, however vague, individuals find themselves identifying with. ${ }^{86}$ This experience cannot be reduced to the individual level, yet it is a multilayered, socially and politically mediated experience, situated in space and time. Looking at the social structure of the uprising that has caused exilement, al-Haj Saleh neither romanticises nor idealises the experience of exile or that of one's homeland ${ }^{87}$ His way of understanding exile grabs its causes and its effects altogether in one conjuncture. He accounts for his subjective, phenomenological experience while situating it in the social fabrics from which it erupted. In what follows, I show how al-Haj Saleh differentiates between the refugee and the exile based on his personal experiences and observations.

\section{Refugees and exiles: proximity and agency}

As he aspires for social change, al-Haj Saleh works on developing conceptual tools to analyse the situation in Syria and the Middle East ${ }^{88}$ While doing so, the question of agency is central to his writings and the way he differentiates the exile from the refugee. The figure of the refugee emerged in the wake of World War II through the management of displacement through legal structures, and humanitarian and scholarly domains. Unlike the exile, the refugee evokes multiple engagements with the state and international bureaucracies. The figure of the exile has no legal references on "the national order of things" but is connected in literary studies as an aesthetic realm of displacement and mobility. ${ }^{89}$ Both figures foreclose different histories of ways of management and administration. Moreover, as al-Haj Saleh was a refugee in Turkey, then an exile in Berlin, he adds proximity and distance, and choice to differentiate between the exile and the refugee. ${ }^{90}$ 
For al-Haj Saleh, through the language of proximity, relationships in space and the relative distance between them render, to my mind, who is a refugee and who is an exile. In mass displacement, the refugee seeks refuge in the nearest place from the conflict and awaits return. However, the exile chooses the exile where they foresee a better life and a more stable, less uncertain future. Refugeehood is the early phase of becoming an exile, as becoming an exile starts with being a refugee, not vice versa. ${ }^{11}$ All places that the exiling authority cannot reach are places of refuge and sanctuary. The further the distance and time far from home, the more exiled the refugee becomes. For example, for al-Haj Saleh, Syrians who live in the north take refuge in Turkey, those who live in the south take refuge in Jordon and Iraq, and in Lebanon for the residents of Damascus and Homs. ${ }^{92}$ When moving farther, the refugee goes beyond being forced to leave and thinks of places in which life opportunities are better. Also, the longer the refugee moves, the longer it takes to return. "It is a question of distance and time," for al-Haj Saleh. ${ }^{93}$ "With a greater distance, say somewhere like Germany, the shortest period of exile is enough to make a refugee stop thinking of return" he clarifies. The longer refugees stay, the more exiled they become.

Al-Haj Saleh does not assume a primacy of state-centric forms of political membership. His differentiation between refugee and exile status indicates that in exile there is more agency and choice than in refugeehood. For al-Haj Saleh, exile, the effect of displacement, is voluntary although forced, similar to 'self-imposed exiles'. Syrian refugees do not go to Germany seeking protection and security, but seeking a less uncertain life that can be planned and invested in. ${ }^{94}$ The purpose of this differentiation, between exiles and refugees, is to analyse the conditions and own the experiences that displaced Syrians pass through. Al-Haj Saleh re-narrates refugees' experiences without portraying them as victims of their conditions or putting them in statist discourse tied up with securitisation, humanitarianism and border control. He argues for interpreting refugees' experiences from their own points of view, in their own words, and challenges how forms of knowledge and ways of seeing refugees are open to present different views of refugee and exile conditions. While a refugee in Turkey for four years, al-Haj Saleh was a founding member of Hamish (Arabic for margin), a cultural initiative in Istanbul using art, film, and literature aimed at challenging representations of Syrians as victims, a dominant discourse in Turkish society, and to produce forms of representation that portray in graphic form refugees following the EU-Turkey refugee deal. ${ }^{95}$ According to al-Haj Saleh, this differentiation is from the viewpoints and lifeworlds of refugees and exiles themselves, to emphasise their agency, which is often exiled by displacement conditions, host communities and hegemonic discourses.

\section{The end of exile: the world of exiles, the exile of the world}

Al-Haj Saleh's critique of the victimisation and the rendering invisible of Syrians is spread throughout his writings. He offers a harsh critique towards the United Nations, its Security Council, the western left and the international 
state-centric order for their (violent) inaction towards Syria. He argues that what Syrians experience is not limited to them. Syria's crisis is no longer Syrian, it is a crisis of the whole world. The descent of peaceful revolution into war, followed by foreign interventions - by the Russians, by Iranian militias from Lebanon and Iraq, then the USA and Turkey - and the rise of ISIS and other Jihadi groups constituted what he calls the 'Syrian Question'. The Syrian Question is "the complicated entanglements between the local struggle against tyranny and religious, sectarian, and ethnic conflicts, along with all the complex and intertwined international interventions" that happened in Syria. ${ }^{96}$ The Syrian Question represents the state of the world in which it is raised, similar to the 'Jewish Question' and the 'Palestinian Question'. Syria's story is the story of the world as "democracy is in crisis all over the world and Syria is a victim of this crisis". ${ }^{97}$

The world is Syrianised and Syria is internationalised. Since the USRussian chemical deal in late 2013, which implied authorisation for the Assad regime to kill Syrians by all means except chemical weapons to not transgress the US 'red line', for al-Haj Saleh, the war in Syria has become globalised..$^{98}$ Syria has become a global symbol of injustice, apathy and amnesia. ${ }^{99}$ The exterminatory, genocidal regime is not a local problem. It is a global problem, as what happened in Syria establishes a global norm and a sovereign possibility in the world of states that can happen elsewhere. Additionally, Syria is located in an already internationalised region, the Middle East, in which global and regional powers are involved in defeating the Arab revolutions, not only Syria. ${ }^{100}$ The cluster of these forces makes of Syria a global question and the war therein is globalised.

Al-Haj Saleh writes against western representations of the Syrian revolution as simply a conflict or a civil war, as this representation obscures Syrians' right to democracy and the extremist nature of the regime. These representations are embedded in 'war-on-terror' discourses. Mainstream attention was shifted to ISIS and refugees while intentionally ignoring the regime's role in cultivating the conditions from which ISIS and the refugees emerge. For alHaj Saleh, these representations are complementary to the war machinery on the battlefield. The less than 7 million Syrians scattered around the world makes of Syria a world crisis. That view of a Syrianised world is not only on the political level, but also realised in the personal realm. Al-Haj Saleh links the destiny and the future of democracy around the world to the freedom of his loved ones, whose destinies are unknown.

Al-Haj Saleh conceptualises 'the world' as an analytical category that equates that of 'exile' and 'home'. ${ }^{101}$ Thinking of the world as an exile makes us think of all the injustices around the world, of which Syria is an example. Such injustices, for al-Haj Saleh, are interconnected and interdependent. $\mathrm{He}$ promotes a relational understanding of the global. The world of exiles is part of, and similar to, the exile of the world. In other words, exiled individuals are in the world, which is an exile itself. The exiling political structure is the world's nation-centric political structure. ${ }^{102}$ Thus, the world's dystopia/utopia is immanent and within. It is here and now, and we bring it into being with 
every action. ${ }^{103}$ That is why for al-Haj Saleh we must change the world in the world without taking higher moral stances regarding the conflicts we are part of as much as we cannot disconnect what is exile from its surrounding action. ${ }^{104}$ In that view, changing Syria is a way towards changing the world and the world's change will befall the Syrians. ${ }^{105}$ Likewise, exiling exile is by rethinking the world's state-centric political system. As the world is the exile, in other words, exiling exile is achieved by exiling today's world.

\section{Conclusion}

The world is an exile in which millions of people are differentially dispossessed. Al-Haj Saleh thinks of the world as home and exile at the same time. ${ }^{106}$ Syria is part of this world/home/exile complex, where the majority of Syrians were exiles in Syria before they were displaced after transformation of the 2011 Syrian revolution into a war. Syrians were exiles as they lived without political rights and legal protection. Hence, for al-Haj Saleh, exile is not exclusively about displacement and uprooting. Exilement, as a cluster of practices and forces, is a modality of rule which is constitutive of Assadist rule in Syria. In that sense, exilement offers analytical views on the outbreak of the Syrian revolution. I presented al-Haj Saleh's perspective on some manifestations of exilement, such as the regime's politics of eternity, marginalisation, non-representation and mass incarceration. The Assadist regime has cultivated over the years an exiling political structure through sectarianism, dynastic rule; and the practices of exilement eventually culminated in genocidal practices that have displaced millions of Syrians around the world. Al-Haj Saleh's perspective on exilification and enjailment shows the way through which exiles undo their exile by transforming exile conditions into liveable spaces.

\section{Acknowledgments}

I would like to thank Magdalena Kmak and Heta Björklund for their extensive feedback on earlier drafts of the chapter. I am grateful to the anonymous reviewers as well. This chapter builds on research I have done with the Aleppo Project at Central European University in Budapest in 2019. I am grateful to the Project's staff for supporting it. I am also thankful for al-Haj Saleh's comments on an earlier draft.

\section{Notes}

1 Enjailment is the translation of the Arabic term Istihbas, coined by the author from the word habs which means imprisonment. Istihbas (as translated by Rana Issa and Suneela Mubayi) is when a prisoner lives in prison as if it is their home. al-Haj Saleh, 2012, 202; al-Haj Saleh, 2018b.

2 The term exilification is the translation of the Arabic term istilja, from the origin luju, which is to take refuge. The author coined this term to account for exiles' lives in exile. 
3 Massouh, 2015b.

4 Massouh, 2015a, 10.

5 Massouh, 2015b.

6 Ghaddar, 2011; Parker, 2018.

7 See al-Haj Saleh, 2019d.

8 See Malkki, 1995; Said, 2000.

9 McKeever, 2020, 5.

10 Massouh, 2015a, 2015b.

11 Massouh, 2015a, 96.

12 Haugbolle, 2015, 18.

13 al-Haj Saleh, 2017b; al-Haj Saleh, 2019c.

14 Young, 2017.

15 Mbembé, 2003, 39.

16 Snyder, 2018.

17 al-Haj Saleh, 2017a.

18 al-Haj Saleh, 2019a; al-Haj Saleh, 2015b.

19 See Ismail, 2018; Dagher, 2019; al-Haj Saleh, 2015 b.

20 al-Haj Saleh, 2018c.

21 al-Haj Saleh, 2018c.

22 al-Haj Saleh, 2017a, 154.

23 al-Haj Saleh, 2018a; al-Haj Saleh, 2017a.

24 al-Haj Saleh, 2018c; Young, 2017.

25 al-Haj Saleh, 2017a, 76.

26 Hussain and Hisham, 2016.

27 Allen, 2017; Atassi and Homsi, 2014.

28 al-Haj Saleh, 2018a.

29 al-Haj Saleh, 2018a; see al-Haj Saleh, 2018c.

30 Mabon, 2017; al-Haj Saleh, 2018d; Afary, 2015; al-Haj Saleh, 2018a.

31 al-Haj Saleh, 2018a.

32 al-Haj Saleh, 2015c.

33 al-Haj Saleh, 2011.

34 al-Haj Saleh, 2019c; al-Haj Saleh, 2017b.

35 Kothari, 2012; see Sznajder and Roniger, 2009; Naguib, 2020.

36 al-Haj Saleh, 2019c.

37 al-Haj Saleh, 2017a; al-Haj Saleh, 2019c.

38 al-Haj Saleh, 2018c; Ismail, 2018; Massouh, 2015b.

39 Ismail, 2018; Massouh, 2015b; al-Haj Saleh, 2012.

40 al-Haj Saleh, 2013; Videmšek, 2014.

41 al-Haj Saleh, 2013.

42 Hadidi, 2002.

43 Ismail, 2018, viii.

44 al-Haj Saleh, 2018e; see Ismail, 2018; Mbembé, 2003; al-Haj Saleh, 2019b; Massouh, 2015b.

45 See al-Haj Saleh, 2018e.

46 al-Haj Saleh, 2012, 16; Massouh, 2015a, 85.

47 al-Haj Saleh, 2018e; Mbembé, 2003.

48 Nebehay, 2018.

49 Al-Haj Saleh also accounts for rape as a form of torture in Syria for men and women; al-Haj Saleh, 2018e.

50 al-Haj Saleh, 2018e. 
51 Amnesty International, 2017.

52 al-Haj Saleh, 2017b.

53 al-Haj Saleh, 2017b.

54 al-Haj Saleh, 2017b.

55 al-Haj Saleh, 2017b.

56 al-Haj Saleh, 2012, 202-203; al-Haj Saleh, 2017b; al-Haj Saleh, 2018 b.

57 al-Haj Saleh, 2017b.

58 Massouh, 2015b.

59 al-Haj Saleh, 2017b.

60 al-Haj Saleh, 2012, 210.

61 al-Haj Saleh, 2018b.

62 al-Haj Saleh, 2017b.

63 Darwīsh, 2007.

64 al-Haj Saleh, 2017b.

65 al-Haj Saleh, 2017b.

66 al-Haj Saleh, $2017 \mathrm{~b}$.

67 al-Haj Saleh, 2018b.

68 al-Haj Saleh, 2015c.

69 al-Haj Saleh, 2015c.

70 al-Haj Saleh, 2015c.

71 al-Haj Saleh, 2015c.

72 al-Haj Saleh, 2019c.

73 al-Haj Saleh, 2019c; see Raz-Krakotzkin, 2013; Raz-Krakotzkin, 2017.

74 See Ahmed, Castañeda, and Fortie, 2003; Çaglar and Schiller, 2018; Schiller and Çağlar, 2013.

75 al-Haj Saleh, 2018b.

76 United Nations High Commissioner for Refugee, 2019.

77 al-Haj Saleh, 2018b.

78 al-Haj Saleh, 2017b.

79 Jefferson, Turner, and Jensen, 2019.

80 al-Haj Saleh, 2015c.

81 al-Haj Saleh, 2015c.

82 al-Haj Saleh, 2015c.

83 al-Haj Saleh, 2019c; see Said, 2000.

84 See Jefferson, Turner, and Jensen, 2019; Massouh, 2015b.

85 Malkki, 1995.

86 Said, 2000.

87 Malkki, 1995, 514.

88 Parker, 2018.

89 Malkki, 1995; Said, 2000, 135; Karatani, 2005.

90 al-Haj Saleh, 2019c.

91 al-Haj Saleh, 2019c.

92 al-Haj Saleh, 2019c.

93 al-Haj Saleh, 2018b.

94 al-Haj Saleh, 2019c.

95 Rygiel and Ilcan, 2017.

96 al-Haj Saleh, 2017a, 24.

97 Young, 2017; See, al-Haj Saleh, 2017d; al-Haj Saleh, 2017e.

98 Lucha Internacionalista and İşçi Demokrasisi Partisi, 2014; al-Haj Saleh, 2015b; al-Haj Saleh, 2016; al-Haj Saleh, 2017a; Feroz, 2017; al-Haj Saleh, 
2017c; Dugaucquier and Gasparini, 2018; al-Haj Saleh, 2015a; Hamid, 2013.

99 Videmšek, 2016.

100 al-Haj Saleh, 2017c; Bishara, 2019; Teti, Abbott, Talbot, and Maggiolini, 2020.

101 al-Haj Saleh, 2018a; Young, 2017.

102 al-Haj Saleh, 2018a; al-Haj Saleh, 2019c.

103 al-Haj Saleh, 2017b.

104 al-Haj Saleh, 2017b.

105 al-Haj Saleh, 2017e.

106 al-Haj Saleh, 2019c.

\section{Bibliography}

Afary, Frieda. 2015. "Syria, Iran, ISIS and the Future of Social Justice: 'In dialogue with Yassin al-Haj Saleh'." Zamaneh Media, Accessed May 29, 2015. https:// en.radiozamaneh.com/24107/.

Ahmed, Sara, Claudia Castañeda, and Anne-Marie Fortie, eds. 2003. Uprootings/ Regroundings: Questions of Home and Migration. London: Routledge.

al-Haj Saleh, Yassin. 2011. "Prisoner of Damascus." The New York Times, April 10, 2011. Accessed July 16, 2019. https://www.nytimes.com/2011/04/11/opinion/11saleh.html/.

al-Haj Saleh, Yassin. 2012. Bil khalās yā shabāb: 16 'āman fi al-sujūn al-sūriyyah [Salvation, Oh Youths! 16 Years in Syria's Prisons]. Beirut: Dar al-Saqi.

al-Haj Saleh, Yassin. 2013. "Al-mansa al-sori... al-mansah al-sorya." [The Forgotten Syria, the Syrian Oblivion]. Al-Hewar al-Mutamadden, Accessed December 20, 2019. http://www.ahewar.org/debat/show.art.asp?aid=341905/.

al-Haj Saleh, Yassin. 2015a. "Forty-four Months and Forty-four Years: The Palestinization of Syrians and the Present World Condition." Accessed April 10, 2020.http://www.yassinhs.com/2015/01/02/forty-four-months-and-fourty-four-years-4palestinization-of-syrians-and-the-present-world-condition/.

al-Haj Saleh, Yassin. 2015b. "Syria and the World: Reactionarism is Back, and Progressing." Translated by Youssef Shayar and Alice Guthrie. Al Jumhuriya, February 19, 2016. Accessed April 8, 2020. https://www.aljumhuriya.net/en/content/syria-and-world-reactionarism-back-and-progressing/.

al-Haj Saleh, Yassin. 2015c. "On the Exiles of Syrians and Syria as Exile.” Translated by Rana Issa. Accessed May 26, 2019. http://www.yassinhs.com/2015/06/07/ on-the-exiles-of-syrians-and-syria-as-exile/.

al-Haj Saleh, Yassin. 2016. "The World's Naked Disgrace." Al Jumhuriya, August 22, 2016. Accessed April 7, 2020. https://www.aljumhuriya.net/en/content/ world $\%$ E2\%80\%99s-naked-disgrace/.

al-Haj Saleh, Yassin. 2017a. The Impossible Revolution: Making Sense of the Syrian Tragedy. Chicago: Haymarket Books.

al-Haj Saleh, Yassin. 2017b. "Freedom: Home, Prison, Exile... and the World." Translated by Rana Issa. Al Jumhuriya, March 25, 2016. Accessed May 26, 2019. http://www.yassinhs.com/2017/04/03/yassin-al-haj-saleh-on-freedom-home-prison-exileand-the-world/. al-Haj Saleh, Yassin. 2017c. "The Re-enchantment of the World." Al Jumhuriya, Accessed October 25, 2017. https://www.aljumhuriya.net/en/content/re-enchantment-world/.

al-Haj Saleh, Yassin. 2017d. "Letters to Samira (4)." Translated by Murhaf Fares. Al Jumhuriya, September 8, 2017. Accessed April 16, 2020. https://www.aljumhuriya. net/en/content/letters-samira-4/. 
al-Haj Saleh, Yassin. 2017e. "Letters to Samira (5)." Translated by Murhaf Fares. $A l$ Jumhuriya, September 13, 2017. Accessed August 11, 2019. https://www.aljumhuriya.net/en/content/letters-samira-5/.

al-Haj Saleh, Yassin. 2018a. "Al abad ka manfea mn al tareek." [Eternity as an Exile from History]. Al Jumhuriya, Accessed July 16, 2019. https://www.aljumhuriya.net/ ar/content / \% D $8 \%$ A $7 \%$ D 9\% $84 \%$ D $8 \%$ A 3 \% D $8 \%$ A $8 \%$ D $8 \%$ A F $\%$ D9\%83\%D9\%85\%D9\%86\%D9\%81\%D9\%89-\%D9\%85\%D9\%86-\%D8\%A7\%D $9 \% 84 \% \mathrm{D} 8 \% \mathrm{AA} \% \mathrm{D} 8 \% \mathrm{~A} 7 \% \mathrm{D} 8 \% \mathrm{~B} 1 \% \mathrm{D} 9 \% 8 \mathrm{~A} \% \mathrm{D} 8 \% \mathrm{AE} /$.

al-Haj Saleh, Yassin. 2018b. "Living in the Temporary." Translated by Suneela Mubayi. Al Jumhuriya, Accessed April 17, 2018. https://www.aljumhuriya.net/en/ content/living-temporary/.

al-Haj Saleh, Yassin. 2018c. "State Extermination, not a 'Dictatorial Regime'." Translated by Alex Rowell. Al Jumhuriya, June 18, 2018. Accessed April 10, 2020. https://www.aljumhuriya.net/en/content/state-extermination-not- $\%$ E2\%80\% 9Cdictatorial-regime $\% \mathrm{E} 2 \% 80 \% 9 \mathrm{D} /$.

al-Haj Saleh, Yassin. 2018d. "The World at the Fascist Moment." Translated by Suneela Mubayi. Al Jumhuriya, August 3, 2018. https://www.aljumhuriya.net/en/ content/world-fascist-moment/.

al-Haj Saleh, Yassin. 2018e. "Love, Torture, Rape... and Annihilation.” Translated by Yasser Azzayyat. Köpfe und Ideen 13, (April). Accessed April 14, 2020. https://www.wiko-berlin. de/en/wikotheque/koepfe-und-ideen/issue/13/letter-from-berlin-articles-to-samira-5/.

al-Haj Saleh, Yassin. 2019a. "Assad or Nobody!.” Translated by Sam Langer and Joel Scott. Rosa Luxemburg Stiftung Publications. https://www.rosalux.de/en/publication/id/40337/assad-or-nobody/.

al-Haj Saleh, Yassin. 2019b. "Terror, Genocide, and the 'Genocratic' Turn.” Translated by Alex Rowell. Al Jumhuriya, Accessed September 19, 2019. https://www.aljumhuriya. net/en/content/terror-genocide-and- $\%$ E2 $\% 80 \% 9$ Cgenocratic $\%$ E2 $\% 80 \% 9 D$-turn/.

al-Haj Saleh, Yassin. 2019c. "Fel manfa wa al watan wa ahalam wa alkitaba." [On Exile, Home, The World and Writing]. Al Jumhuriya, Accessed December 19, 2019. https://bit.ly/3CShx3H.

al-Haj Saleh, Yassin. 2019d. "Syria War: The Love of My Life Disappeared Six Years Ago, But Still I Cling to Hope.” Middle East Eye, December 26, 2019. Accessed April14,2020.http://www.middleeasteye.net/opinion/syria-war-love-my-life-disappearedsix-years-ago-still-i-cling-hope/.

Allen, Ira. 2017. "Falling Apart Together: On Viewing Ali Atassi's Our Terrible Country from Beirut." Screen Bodies 2, no. 2: 78-90.

Amnesty International. 2017. Syria: Tens of Thousands of Disappeared must not be Forgotten, Accessed April 14, 2020. https://www.amnesty.org/en/latest/news/2017/08/ syria-tens-of-thousands-of-disappeared-must-not-be-forgotten/.

Bishara, Azmi. 2019. "Remarks on External Factors in Democratic Transition." AlMuntaqa 2, no. 2: 40-60.

Çaglar, Ayse, and Nina Glick Schiller. 2018. Migrants and City-Making: Dispossession, Displacement, and Urban Regeneration. Durham: Duke University Press.

Dagher, Sam. 2019. Assad or We Burn the Country: How One Family's Lust for Power Destroyed Syria. New York, Boston, London: Little, Brown and Company.

Darwīsh, Mạ̣mūd. 2007. "Edward Said: A Contrapuntal Reading." Translated by Mona Anis. Cultural Critique 67, no. 1: 175-182.

Dugaucquier, Matilde, and Mauro Gasparini. 2018. "Interview with Yassin Al-Haj Saleh." International Viewpoint, Accessed February 5, 2018. https://internationalviewpoint.org/spip.php?article5361/. 
Feroz, Emran. 2017. "Syria, The Left, and The World." Al Jumhuriya, Accessed April 6, 2017. https://www.aljumhuriya.net/en/en/the-role-of-the-intellectual/syria_the_ left_and_the_world/.

Ghaddar, Hanin. 2011. "Talking to Syrian dissident Yassin Al Haj Saleh. Activist in Hiding." Now Lebanon, Accessed September 8, 2011. https://ademocracynet.com/ index.php?page $=$ news \&action $=$ Detail $\&$ id $=4354$

Hadidi, Subhi. 2002. "Bashar Assad Teaches Visiting Members of U.S. Congress How to Fight Terrorism." The Middle East Media Research Institute, January 16, 2002.Accessed April13,2020.https://www.memri.org/reports/bashar-assad-teachesvisiting-members-us-congress-how-fight-terrorism/.

Hamid, Shadi. 2013. "The U.S.-Russian Deal on Syria: A Victory for Assad." The Atlantic, September 14, 2013. Accessed April 7, 2020. https://www.theatlantic.com/ international/archive/2013/09/the-us-russian-deal-on-syria-a-victory-for$\operatorname{assad} / 279680 /$.

Haugbolle, Sune. 2015. "Moving through the Interregnum: Yassin al-Haj Saleh in the Syrian Revolution." Middle East Journal of Culture and Communication 8, no. 1: 13-36.

Hussain, Murtaza, and Marwan Hisham. 2016. "Syria's 'Voice of Conscience' Has a Message for the West.” The Intercept, October 26, 2016. Accessed April 7, 2020. https://theintercept.com/2016/10/26/syria-yassin-al-haj-saleh-interview/.

Ismail, Salwa. 2018. The Rule of Violence. Cambridge: Cambridge University Press. Jefferson, Andrew, Simon Turner, and Steffen Jensen. 2019. "Introduction: On Stuckness and Sites of Confinement." Ethnos 84, no. 1: 1-13.

Karatani, Rieko. 2005. "How History Separated Refugee and Migrant Regimes: In Search of Their Institutional Origins." International Journal of Refugee Law 17, no. 3: 517-541.

Kothari, Uma. 2012. "Contesting Colonial Rule: Politics of Exile in the Indian Ocean.” Geoforum 43, no. 4: 697-706.

Lucha Internacionalista and İşçi Demokrasisi Partisi. 2014. "Yassin al-Haj Saleh: 'The International Left is Suffering a Major Crisis'." SocialistCore.org. http://www. socialistcore. org/?p=493/.

Mabon, Simon. 2017. "Sovereignty, Bare Life and the Arab Uprisings." Third World Quarterly 38, no. 8: 1782-1799.

Malkki, Liisa H. 1995. "Refugees and Exile: From 'Refugee Studies' to the National Order of Things." Annual Review of Anthropology 24, no. 1: 495-523.

Massouh, Firas. 2015a. Searching for Salvation: Yassin al-Haj Saleh and the Writing of Modern Syria. MA Thesis, University of Melbourne.

Massouh, Firas. 2015b. "The Beast of Syrian Modernity: The Prison in the Writings of Yassin al-Haj Saleh.” Arena Journal 43/44. https://search.informit.org/ doi/10.3316/ielapa.512541270815038/.

Mbembé, J.-A. 2003. "Necropolitics." Translated by Libby Meintjes. Public Culture 15, no. 1: 11-40.

McKeever, David. 2020. Exiled Activism: Political Mobilization in Egypt and England. London: Routledge.

Naguib, Rim. 2020. "The Ideological Deportation of Foreigners and 'Local Subjects of Foreign Extraction' in Interwar Egypt”. Arab Studies Journal 28, no. 2 (Fall). Accessed December 13, 2020. https://www.jadaliyya.com/Details/42065/.

Nebehay, Stephanie. 2018. "Thousands of Women, Men, Children Raped in Syria's War: U.N. Report.” Reuters, March 15, 2018. Accessed April 14, 2020. https://www. reuters.com/article/us-mideast-crisis-syria-warcrimes-sexual-idUSKCN1GR1PZ/.

Parker, Thomas. 2018. “On Syria's Impossible Revolution.” Bosphorus Review of Books. https://bosphorusreview.com/on-syrias-impossible-revolution/. 
Raz-Krakotzkin, Amnon. 2013. "Exile, History and the Nationalization of Jewish Memory: Some Reflections on the Zionist Notion of History and Return." Journal of Levantine Studies 3, no. 2: 37-70. Accessed April 15, 2020. https://levantine-journal.org/product/exile-history-and-the-nationalization-of-jewish-memorysome-reflections-on-the-zionist-notion-of-history-and-return/.

Raz-Krakotzkin, Amnon. 2017. "Exile Within Sovereignty: Critique of 'The Negation of Exile' in Israeli Culture." In The Scaffolding of Sovereignty: Global and Aesthetic Perspectives on the History of a Concept, edited by Zvi Ben-Dor Benite, Stefanos Geroulanos, and Nicole Jerr, 393-420. New York: Columbia University Press.

Rygiel, Feyzi Baban, and Kim Suzan Ilcan. 2017. "Playing Border Politics with Urban Syrian Refugees. Legal Ambiguities, Insecurities, and Humanitarian Assistance in Turkey." Movements. Journal for Critical Migration and Border Regime Studies 3, no. 2: 81-102. Accessed January 17, 2020. http://movements-journal.org/issues/05.turkey/06.baban,ilcan,rygiel--playing-border-politics-with-urban-syrian-refugees.html/.

Said, Edward W. 2000. Reflections on Exile and Other Essays. Cambridge, MA: Harvard University Press.

Schiller, Nina Glick, and Ayse Çağlar. 2013. "Locating Migrant Pathways of Economic Emplacement: Thinking Beyond the Ethnic Lens." Ethnicities 13, no. 4: 494-514.

Snyder, Timothy. 2018. "Vladimir Putin's Politics of Eternity." The Guardian, March 15, 2018. Accessed April 9, 2020. https://www.theguardian.com/news/2018/mar/16/ vladimir-putin-russia-politics-of-eternity-timothy-snyder/.

Sznajder, Mario, and Luis Roniger, eds. 2009. The Politics of Exile in Latin America. Cambridge: Cambridge University Press.

Teti, Andrea, Pamela Abbott, Valeria Talbot, and Paolo Maggiolini. 2020. Democratisation Against Democracy How EU Foreign Policy Fails the Middle East. Cham: Palgrave Macmillan.

United Nations High Commissioner for Refugee. 2019. Global Trends - Forced Displacement in 2018. Geneva: United Nations High Commissioner for Refugee. https://www.unhcr.org/globaltrends2018/

Videmšek, Bostjan. 2014. "The Hat of Invisibility”. PULSE, Accessed May 13, 2014. https://pulsemedia.org/2014/05/13/the-hat-of-invisibility/.

Videmšek, Boštjan. 2016. "Yassin al-Haj Saleh: 'Syria is a Unique Symbol of Injustice, Apathy and Amnesia'." Chronikler, Accessed January 20, 2016. http://chronikler. com/middle-east/iraq-and-the-levant/yassin-al-haj-saleh/.

Young, Michael. 2017. "The Triumph of Politicide." Carnegie Middle East Center, Accessed July 17, 2019. https://carnegie-mec.org/diwan/72850/. 